\title{
OBITUARY
}

\section{Professor D. J. WISEMAN, OBE, MA, DLit, FBA, FSA (1918-2010)}

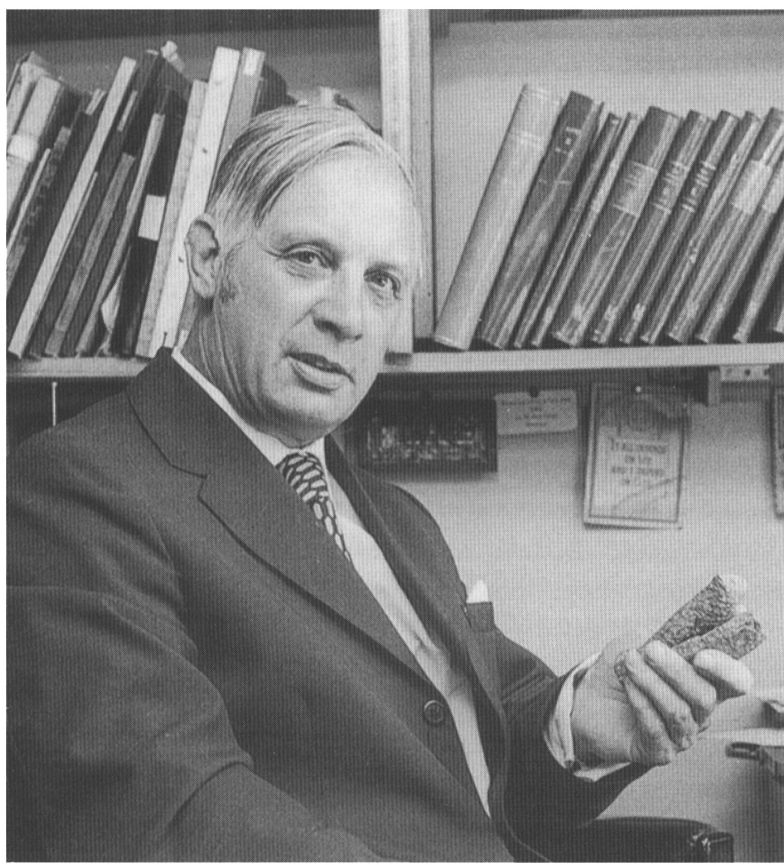

Donald Wiseman died on 2 February aged ninety-one. A service of thanksgiving for his life and work took place at All Souls' Church in Langham Place, London W1, on 4 June. He was a longterm servant of the British Institute for the Study of Iraq, during his time called the British School of Archaeology in Iraq, acting for it in many capacities. He also sat on the councils of the British School of Archaeology in Jerusalem, the British Institute for Archaeology at Ankara and the British Institute at Amman for Archaeology and History, and was a stalwart of the Society for Old Testament Study and Tyndale House. These academic duties, though substantial, were only some of the many voluntary activities that characterized his life.

Donald John Wiseman was born in Hampshire on 25 October 1918. His father, P. J. Wiseman, was a senior accountant in the Royal Air Force who, during service in Mesopotamia, collected cuneiform tablets and other artefacts, and made a study of them in his spare time. His interest in ancient Iraq lay in its potential as an aid to the understanding of the bible. The outcome was two books, New Discoveries in Babylonia about Genesis (1936) and Creation Revealed in Six Days (1948), which put forward new ideas regarding the authorship of the Old Testament and the interpretation of the creation narrative. These ideas won some adherents, and Donald Wiseman was moved to return to and expand on his father's work after his retirement, in a book entitled Clues to Creation in Genesis (1997). The father's academic work was a strong intellectual influence on the son.

Donald Wiseman was educated at Dulwich College and King's College London. As an undergraduate in London he soon transferred from history to Hebrew and Assyrian, in the hope of learning some of the Semitic languages that, following his father's example, he believed would provide evidence with which to assert the reliability of the bible. He made fast progress in Hebrew but in his desire to learn Assyrian, as Akkadian was then known, he came up against Sidney Smith, the University of London's lecturer in "Accadian Assyriology" and founding editor of this journal. Smith was then Keeper of Egyptian and Assyrian Antiquities at the British Museum. His appointment as an honorary lecturer at King's College was matched by the appointment of his 
junior colleague at the museum, C. J. Gadd, as lecturer in "Sumerian Assyriology". The university's strategy of enlisting busy museum staff as unsalaried teachers of Assyriology is a reminder that British universities have always sought to cover neglected subjects by cut-price means.

In the circumstances it would not be surprising if Smith was somewhat jealous of the time he gave to teaching, and it seems that he thwarted Wiseman's plans for many months. First he told Wiseman to come back only when he knew Hebrew. When Wiseman duly did so, Smith palmed him off on the historian of religion S. H. Hooke, who was Professor of Old Testament at King's College but had himself started a small class in Akkadian. Faced with Wiseman's persistence and desire for more advanced work, Smith then sent him to read Mesopotamian archaeology with V. Gordon Childe and Kathleen Kenyon at the university's Institute of Archaeology. Eventually he gave in and taught Wiseman himself but, as the international situation deteriorated, very soon came up with the excuse that he could not waste his time with a student who, as Wiseman himself put it, "would be killed in the coming war". Wiseman had to continue his Assyriological studies without him, graduating in 1939. This episode in the history of Assyriology at the University of London is better told in Wiseman's autobiography, Life Above and Below (2003), to which this obituary is much indebted.

War then came as expected but Wiseman did not suffer the fate that Smith had predicted for him. He served with great distinction in the Royal Air Force, as personal assistant to Air ViceMarshal Park during the Battle of Britain and as chief intelligence officer in the Mediterranean theatre during the Allies' advance on Tunis and invasion of Italy. When the campaign reached Rome he visited the Pontifical Biblical Institute to discover that its Assyriologists, Fathers Deimel and Pohl, were alive and well. From Pohl he bought issues of the institute's journal, Orientalia, and sent them to his reluctant teacher at the British Museum.

Swiftly demobilized after the war Wiseman went up to Wadham College, Oxford, to read Oriental Languages. He specialized in Hebrew with G. R. Driver and read Akkadian with O. R. Gurney, equally swiftly demobilized. With the latter soon absent in Turkey, Wiseman then began teaching Akkadian to others, among them J. V. Kinnier Wilson, who went on to lecture in Assyriology at Cambridge. On graduating in 1948 Wiseman was invited by Sidney Smith to join the British Museum as Assistant Keeper. Clearly he had proved himself. Smith was about to retire from the museum to become Professor of Ancient Semitic Languages and Civilizations at the School of Oriental and African Studies (SOAS) in the University of London, but had time to set Wiseman to work on cuneiform tablets deriving from C. L. Woolley's excavations in the Amuq plain at Tel Açana (Tell Atchana, ancient Alalakh). Seasons immediately before and after the war had produced large archives from two different periods. Smith also wanted Wiseman to become his research student, working on the language of the texts, but this time it was Wiseman who made his excuses. The results of Wiseman's labours on Alalakh tablets were published by the British Institute of Archaeology at Ankara in 1953 as a catalogue and index, with hand copies of the cuneiform tablets, under the title The Alalakh Tablets; supplementary studies appeared in four articles in the Journal of Cuneiform Studies.

Smith's successor as Keeper, C. J. Gadd, then directed Wiseman's energies towards the Babylonian historiographical texts known as chronicles, in order to update the earlier contributions of L. W. King, Smith and Gadd. The Chronicles of Chaldean Kings (625-556 B.C.) in the British Museum appeared in 1956. The book significantly enlarged the corpus of extant chronicles. One of the pieces published for the first time holds a report of Nebuchadnezzar's capture of Jerusalem in 597 BC, a passage that must have especially pleased its editor. It was also Wiseman's job to complete Sidney Smith's project of publishing all the museum's Old Assyrian tablets, contributing thirty cuneiform copies to their joint publication, Cuneiform Texts from Cappadocian Tablets in the British Museum, Part V (1956). Another task was to write a check-list of the museum's holdings of Uruk and Early Dynastic cylinder seals, which appeared in 1962 as Catalogue of the Western Asiatic Seals in the British Museum 1.

Among other museum duties Wiseman supervized the return of the Assyrian monumental sculpture from wartime storage under the Aldwych, where it had been kept safe alongside the royal china, and designed the Room of Writing, a gallery filled with an extraordinarily comprehensive display of cuneiform tablets that excited Assyriologists more surely than it impressed less 
academic minds. Further fruits of museum duty were the illustrated booklets Illustrations from Biblical Archaeology (1958), Cylinder Seals of Western Asia (1959) and Fifty Masterpieces of Ancient Near Eastern Art (1960), the latter jointly written with R. D. Barnett, who had become Keeper of Western Asiatic Antiquities in 1955 when Gadd left to succeed Smith at the university.

During the 1950s the British Museum gave Wiseman leave to act as epigrapher on the British School of Archaeology in Iraq's excavations led by M. E. L. Mallowan at Nimrud (Kalakh), the Assyrian imperial capital founded by Ashurnașirpal II. Wiseman began this work in the second season, in 1950, and returned for the third and fifth seasons. He wrote up the finds between 1950 and 1955 in eight contributions to this journal. It also fell to him to publish the tablets found in the temple of Nabû in 1955 and subsequent years. The task began with the shattered remains of eight very large tablets inscribed with treaties of loyalty binding Median chieftains to protect the accession of Esarhaddon's heirs, Ashurbanipal and Šamaš-šum-ukîn. Conservation was effected by Cyril Bateman in the British Museum, so promptly and so well that Wiseman was able to publish his edition of The Vassal-Treaties of Esarhaddon in 1958. It also came out as the first part of Volume 20 of this journal. Of all his Assyriological books, this one gave Wiseman the greatest satisfaction, for he later confided that it elicited almost no letters of correction from colleagues. Indeed, it remained the standard edition of the treaties for thirty years, a good life for an editio princeps.

The other tablets from the temple of Nabû took much longer to process. These were exemplars, often horribly mutilated, of all manner of texts of the Babylonian scribal tradition, from narrative poetry to omen compendia. Periods spent by Wiseman in Baghdad in the 1960s allowed the copying of about half the tablets. Some, like manuscripts of Gilgameš and the Poem of the Righteous Sufferer, he made available piecemeal in Iraq. The labour of cataloguing the tablets and copying the cuneiform was finished by J. A. Black during his time as Director of the British Archaeological Expedition to Iraq, and published by the British School of Archaeology in Iraq in 1996 as Literary Texts from the Temple of Nabî (Cuneiform Texts from Nimrud IV).

In 1961 Wiseman followed Smith and Gadd two blocks north of the museum to the School of Oriental and African Studies, where he became Professor of Assyriology. His inaugural lecture of 27 February 1962 combined an essay on the history of Assyriology, especially British Assyriology, with a survey of the scope and prospects of the subject. The published form, a booklet entitled The Expansion of Assyrian Studies, is a useful supplement to E. A. Wallis Budge's memoir, The Rise and Progress of Assyriology (1925). Budge, who was Sidney Smith's predecessor-but-one at the British Museum, died in 1934 and Wiseman never knew him, but the old man's memory weighed heavily on his successors in the Department of Egyptian and Assyrian Antiquities, and it may be that Wiseman's lecture was conceived in conscious emulation of Budge's book. Budge's characteristic vindictiveness and prejudices were happily absent from Wiseman's straightforward prose.

At SOAS Wiseman joined H. W. F. Saggs, then Reader in Assyriology in the University of London. This was a glorious period when universities were enjoying fat years of expansion, a situation well documented in Wiseman's survey of European Assyriology, commissioned by the Council of Europe and entitled Assyriology in Europe: A Report (1967). Three years after his arrival at SOAS the ancient Near Eastern section was supplemented by the appointment of J. D. Hawkins to establish teaching and research in Hittite. When Saggs departed to Cardiff the section's numbers were maintained by the successive appointments of A. R. Millard, J. N. Postgate, M. J. Selman and Johanna Firbank as lecturers in Assyriology. Among Wiseman's students at SOAS were Millard, who went on to become professor at the University of Liverpool, Stephanie Dalley (then Page), who taught Assyriology at Edinburgh and Oxford, Ali Yaseen Ahmad (al-Jibouri), who became professor at Mosul University, and H.I.H. Prince Takahito Mikasa, who founded the Middle East Culture Centre in Tokyo. It was a fortunate time to be a senior academic, and Wiseman's good fortune was compounded by the talents of his colleagues. His successful edition of the Gilgameš tablet from Nimrud (Iraq 37 [1975] 157--63) owes much to their contributions to a text-reading seminar whose proceedings have entered section folklore (see fn. 6).

The section's strength in staffing allowed Wiseman leaves of absence to act as Joint Director of the British School of Archaeology in Iraq from 1961 to 1965, a position that gave him the 
opportunity in 1963 of continuing his work on the tablets excavated at Nimrud. In 1966 he returned to Iraq as joint epigrapher with Barbara Mallowan (then Parker) for the third season of the School's excavations at Tell Al-Rimah in northern Iraq, led by the late David Oates. The season's yield in cuneiform tablets was forty Middle Assyrian pieces; some of them belonged to an archive of the reign of Shalmaneser I, of which the bulk had been discovered in the previous season. Saggs and Wiseman produced rapid editions of the material in Iraq 30 (1968).

At SOAS Wiseman became Head of the Department of Languages and Cultures of the Near and Middle East in 1981. It was the year that Mrs Thatcher's axe fell, and the universities entered a lean era of severe austerity. To avert catastrophe Wiseman and many senior colleagues took early retirement, in a cull of professors that is still recalled in shocked undertone. He had been elected Fellow of the British Academy in 1966. A year after leaving SOAS he delivered the Academy's twenty-first series of Schweich lectures, published in 1985 as Nebuchadrezzar and Babylon. This was an opportunity to rehearse several new ideas, especially on the location of the legendary Hanging Gardens, a topic that Wiseman discussed in two other essays. It also gave occasion for him to publish a fragment of a Babylonian astronomical diary referring to the presence of Alexander the Great in Babylon. This was a small legacy of British Museum days, when Wiseman collaborated with Abraham Sachs of Brown University in identifying many hundreds of tablets of astronomical and other content.

Wiseman's long association with the British School of Archaeology in Iraq began in 1953, when he succeeded Margaret Munn-Rankin as an editor of this journal. From Volume 15 he shared the burden first with M. E. L. Mallowan and then with J. D. Hawkins, before bowing out with Volume 40 in 1978. He first sat on the School's council in 1955 and was its Vice-Chairman from 1966 to 1970, when he succeeded Mallowan as Chairman. In presiding over meetings he displayed characteristic good nature and detachment. He stood down in 1988 and was elected a VicePresident in appreciation. As a mark of the School's gratitude for their long years of service, Volume 50 of this journal was dedicated jointly to Barbara Mallowan and Wiseman, who that year reached the ages of eighty and seventy respectively. On Lady Mallowan's death in 1993, Wiseman succeeded her as President, a position that he held until increasing frailty persuaded him in 2000 that he could not bring to the role the active participation in the School's affairs that he believed should properly be expected. Two years earlier Volume 60 of the journal coincided with Wiseman's eightieth birthday and was prefaced by a formal letter of congratulation that recorded the School's gratitude and appreciation for nearly half a century's service.

Donald Wiseman's academic career in the British Museum, the University of London and the learned societies is a matter of public knowledge. Through it all his main motivation was his Christian faith. His lifelong study of the bible ensured that his energies as a scholar were only partly devoted to Assyriology. He published much in Old Testament studies, where he was a prolific contributor to The New Bible Dictionary (1962), The Zondervan Pictorial Bible Encyclopedia of the Bible (1975) and The Illustrated Bible Dictionary (1981). Time and again he wrote on how Near Eastern archaeology could shed light on biblical studies, and edited volumes entitled Notes on Some Problems in the Book of Daniel (1965, with T. C. Mitchell), Peoples of Old Testament Times (1973), Archaeology and the Bible: An Introductory Study (1979, with E. Yamauchi) and Essays on the Patriarchal Narratives (1980, with A. R. Millard). His last major work of scholarship was a study of the books of Kings for the Tyndale Old Testament Commentaries, 1 and 2 Kings: An Introduction and Commentary (1993).

Wiseman's work as chairman of the Scripture Gift Mission and translator of the New International Version of the bible can only gain passing mention here, but his autobiography makes it clear that it was in spreading the word of the bible that his vocation truly lay. It was a vocation forged in his family background and reinforced by a lifetime of studying ancient Iraq, just as he had envisaged as a young man.

A.R.G. 